\title{
Charles Darwin and the artificial comb
}

William D. J. Kirk

School of Life Sciences,

Keele University,

Newcastle-under-Lyme,

Staffordshire ST5 5BG,

UK

email: w.d.j.kirk@keele.ac.uk

Tel.: +44 1782733517 


\title{
Charles Darwin and the artificial comb
}

\author{
William D. J. Kirk
}

The IBRA Eva Crane Historical Collection contains a brief, undated acknowledgment letter from Charles Darwin to Thomas White Woodbury. The recipient, Thomas Woodbury (18181871), was a journalist and beekeeper in Devon, UK, who devoted much time to trying to improve the quality of honey bees and beekeeping (Brown, 1994). In 1860, he developed a wooden hive with 10 movable frames and bee space, which led to the national hive, widely used in England today. He was particularly concerned to improve the quality of the bees used for beekeeping by finding better strains that he could import from overseas. He imported Ligurian (or Italian) queens (Apis mellifera ligustica) from Switzerland in 1859 and also exported them to Australia in 1862.

The letter is reproduced (Figure 1) and transcribed below. It has recently been put on display in the Honey Bee Exhibition at Quince Honey Farm, South Molton, Devon, UK (www.quincehoneyfarm.co.uk).

\author{
I thought \& still think that \\ I wrote to thank you \\ for the artificial comb, \\ which interested me much; \\ but if you did not get a \\ letter, it must have been lost \\ or I did not write it. \\ with apologies, Dear Sir \\ \& my best thanks \\ Yours vy faithfully \\ C. Darwin
}

The background to this letter can be discovered by searching the Darwin Correspondence Project (www.darwinproject.ac.uk), where one can read and search the full texts of more than 8,500 of Charles Darwin's letters, with complete transcripts of all the known letters that he wrote and received up to the year 1871. A transcript of the acknowledgment letter is in the database (Darwin Correspondence Project, Letter no. 4050) and this identifies the letter from Woodbury to which it is a response and provides a transcript (Darwin Correspondence Project, Letter no. 4049) (Burkhardt, Porter, Dean, Topham \& Wilmott, 1999).

Mount Radford, Exeter.

17th March 1863

\section{Dear Sir}

I am exceedingly obliged to you for favouring me with specimens of bees and their comb from Africa.1 I suppose the bees are apis Adansonii as they appear to tally with the description of that species in the Naturalist's Library. 2 They appear almost identical with apis Ligustica with the exception of being smaller. Very careful comparison of their comb with that of mellifica enables me to pronounce the cells exactly the same $\langle$ size $\rangle$ 
How singular it appears that this small bee as well as the large species apis testacea do not vary one iota in the size of their cells from our European species! It would be very interesting to ascertain if the small species so common in India (apis Indica) also makes the same sized cell.

These bees being so small would not repay the trouble of attempting to import them, but I still have a strong impression that the large Indian species (apis dorsata) would be very valuable. $\langle\mathrm{I}\rangle$ dare say you may have seen my queries regarding them together with the answers in "The Field." Little practical information has resulted, nor do I yet see my way to taking any steps for their importation. Have you noticed that the first four hives of Ligustica sent by me to Australia have all got there in safety?

I have never heard if the piece of partially completed artificial comb proved at all interesting to you

Yours greatly obliged

T W Woodbury

C. Darwin Esq

It appears likely that Woodbury's interest in bee variation was in relation to finding better strains to import to England.

Darwin's interest in bee variation was no doubt in relation to natural selection. He discussed the construction of the wax cells of the honey bee and some experiments he carried out with wax comb in beehives in a section on "Cell-making instinct of the hive-bee" in Chapter 7 on Instinct in The Origin of Species (Darwin, 1859). He also wrote a letter, which was forwarded to the German journal Bienen Zeitung, enquiring whether there was marked variation in the honey bee kept in various regions of Germany (Darwin, 1862). A survey of Darwin's particular interest in bees and his experiments with them was published in Bee World many years ago (Brian \& Crane, 1959), but still makes interesting reading today. It is available online in the Bee World archive (www.tandfonline.com/loi/tbee20), which is free to IBRA members via the IBRA web site (www.ibra.org.uk).

\section{References}

Brian, A. D. \& Crane, E. E. (1959). Charles Darwin and bees. Bee World, 40, 297-303. doi:10.1080/0005772X.1959.11096750.

Brown, R. (1994) Great masters of beekeeping. Mytholmroyd, UK: Northern Bee Books.

Burkhardt, F., Porter, D. M., Dean, S. A., Topham, J. R., \& Wilmott, S. (Eds.). (1999). The correspondence of Charles Darwin. Volume 11. 1863. Cambridge: Cambridge University Press.

Darwin, C. (1859) On the origin of species by means of natural selection or the preservation of favoured races in the struggle for life. London: Murray. 
Darwin, C. (1862) Findet bei den Bienen in den verschiedenen Theilen Deutschlands ein Unterschied statt? [Is there a difference between the bees in different parts of Germany?] Bienen Zeitung, 18 (20 August), 145.

Darwin Correspondence Project, “Letter no. 4049,” accessed on 22 April 2016, http://www.darwinproject.ac.uk/DCP-LETT-4049

Darwin Correspondence Project, “Letter no. 4050,” accessed on 22 April 2016, http://www.darwinproject.ac.uk/DCP-LETT-4050 


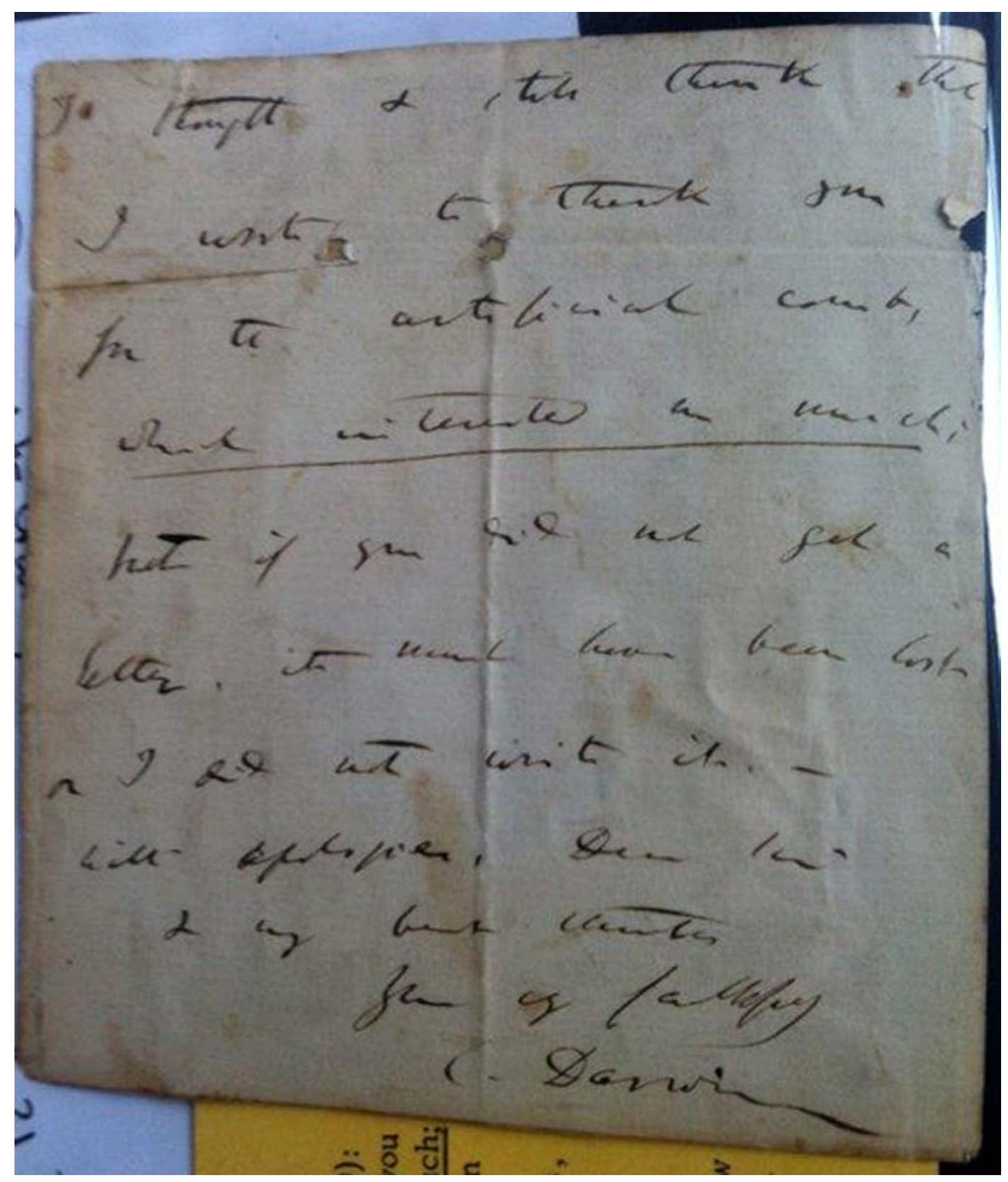

Figure 1. The acknowledgment letter from Charles Darwin to Thomas White Woodbury, which is part of the IBRA Eva Crane Historical Collection (photo: IBRA). 